\title{
Aplikasi Plant Growth Promoting Rhizobacteria dalam Meningkatkan Produktivitas Bawang Merah di Lahan Pasir Pantai
}

\section{The Application of Plant Growth Promoting Rhizobacteria to Improve Shallot Productivity on Sandy Coastal Land}

\author{
Sumiyati Tuhuteru ${ }^{1 *}$, Endang Sulistyaningsih ${ }^{2}$, dan Arif Wibowo ${ }^{3}$ \\ ${ }^{1}$ Program Studi Agroteknologi, Sekolah Tinggi Ilmu Pertanian Petra Baliem Wamena \\ Jl. Sanger, Potikelek-Wamena, Jayawijaya, Papua, 99511, Indonesia \\ ${ }^{2}$ Program Studi Agronomi, Fakultas Pertanian, Universitas Gadjah Mada Yogyakarta, Indonesia \\ ${ }^{3}$ Program Studi Perlindungan Tanaman, Fakultas Pertanian, Universitas Gadjah Mada Yogyakarta, Indonesia
}

Diterima 25 Juli 2018/Disetujui 25 Februari 2019

\begin{abstract}
The use of Plant Growth Promoting Rhizobacteria (PGPR) is one of the most effective techniques to improve fertility of sandy coastal lands. The purpose of this research was to obtain the most effective isolate of PGPR for the growth of three shallot cultivars in the sandy coastal land. The research was conducted in August-November 2015 at Samas sandy coastal land, Bantul. The two-factor treatments were assigned in a randomized complete block design with three replications. The first factor was shallot cultivars, consisted of Crok, Tiron, and Tuk-tuk, while the second factor was the PGPR suspension, i.e. control (without PGPR), PGPR BP25.2 isolate (Bacillus methylotrophicus), BP25.6 isolate (Bacillus amyloliquofaciens), BP25.7 isolate (Bacillus subtilis), BrSM 4 isolate (Burkholderia cepacia), and BrSG 5 isolate (Burkholderia seminalis). The results showed that all PGPR isolates tested had the ability to produce IAA, with the highest amount of IAA concentration produced by BrSG 5 isolate (Burkholderia seminalis) combined with the three cultivars $\left(22.46 \mathrm{mg} \mathrm{kg}^{-1}, 28.61 \mathrm{mg} \mathrm{kg}^{-1}\right.$, $\left.41.41 \mathrm{mg} \mathrm{kg}^{-1}\right)$. BP25.2 isolate (Bacillus methylotrophicus) effectively induced $N(0.05 \%)$, whereas BP25.7 isolate (Bacillus subtilis) effectively induced $P(0.22 \mathrm{ppm})$.
\end{abstract}

Keywords: Bacillus, bacteria, marginal land

\section{ABSTRAK}

Penggunaan Plant Growth Promoting Rhizobacteria (PGPR) merupakan salah satu teknik yang efektif untuk meningkatkan status kesuburan wilayah pesisir pantai. Penelitian ini bertujuan untuk mendapatkan isolat PGPR yang efektif untuk pertumbuhan tiga kultivar bawang merah di lahan pasir pantai. Penelitian ini dilakukan pada bulan Juni sampai dengan Agustus 2016 di lahan pasir pantai Samas-Bantul. Penelitian disusun dalam rancangan kelompok lengkap teracak dengan dua faktor dan tiga ulangan. Faktor pertama adalah kultivar bawang merah, yakni kultivar Crok, Tiron, dan Tuk-tuk. Faktor kedua adalah suspensi PGPR, yang terdiri atas kontrol (tanpa PGPR), isolat PGPR BP25.2 (Bacillus methylotrophic), isolat BP25.6 (Bacillus amyloliquofaciens), isolat BP25.7 (Bacillus subtilis), isolat BrSM 4 (Burkholderia cepacia), dan isolat BrSG 5 (Burkholderia seminalis). Hasil penelitian menunjukkan bahwa semua isolat PGPR yang diuji memiliki kemampuan memproduksi IAA, dengan konsentrasi tertinggi ditunjukkan oleh isolat BrSG.5 (Burkholderia seminalis) yang dikombinasikan dengan ketiga jenis kultivar (22.46 mg kg-1, $\left.28.61 \mathrm{mg} \mathrm{kg}^{-1}, 41.41 \mathrm{mg} \mathrm{kg}^{-1}\right)$. Isolat BP25.2 (Bacillus methylotrophicus) efektif menghasilkan N(0.05\%), sedangkan isolat BP25.7 (Bacillus subtilis) efektifmenghasilkan residu $P(0.22 \mathrm{ppm})$.

Kata kunci: Bacillus, bakteri, lahan marginal

\section{PENDAHULUAN}

Bawang merah (Allium cepa $\mathrm{L}$.) merupakan komoditas sayuran unggulan yang sejak lama telah diusahakan oleh

\footnotetext{
* Penulis untuk korespondensi. e-mail: tuhuteru.umy@gmail.com
}

petani secara intensif. Bawang merah dapat digunakan sebagai bumbu masakan (flavor), sayuran (acar dan salad), dan produk olahan (bawang goreng). Ekstrak umbi bawang merah saat ini sedang dipelajari sebagai obat tradisional (antimicrobial, anticancer, dan anti-inflammatory) (Sari et al., 2017). 
Lahan marginal pasir pantai adalah lahan potensial yang hingga saat ini kurang mendapat perhatian, khususnya di Indonesiaa yang memiliki luasan $81,000 \mathrm{~km}$ pasir pantai (Badan Riset Kelautan dan Perikanan, 2007). Dengan asumsi bahwa setengah dari pasir pantai tersebut merupakan lahan pasir pantai dengan lebar sekitar $1 \mathrm{~km}$, Indonesia memiliki 4.05 juta ha lahan pasir pantai (Parwata et al., 2014). Lahan pasir pantai merupakan kelompok lahan marginal dalam bidang pertanian yang memiliki produktivitas yang rendah. Produktivitas lahan pasir pantai yang rendah disebabkan oleh faktor pembatas yang berupa kemampuan memegang dan menyimpan air rendah, infiltrasi dan evaporasi tinggi, kesuburan dan bahan organik sangat rendah, dan efisiensi penggunaan air rendah (Kertonegoro, 2001; Al-Omran et $a l .$, 2004). Produktivitas tanah dipengaruhi oleh kandungan C organik, KPK, tekstur, dan warna. Tanah pasir dicirikan bertekstur pasir, struktur berbutir, konsistensi lepas, sangat porous, sehingga daya sangga air dan pupuk sangat rendah, miskin hara dan kurang mendukung pertumbuhan tanaman. Tekstur tanah pasir ini sangat berpengaruh pada status dan distribusi air, sehingga berpengaruh pada sistem perakaran, kedalaman akar (Walter et al., 2000; Oliver dan Smettem, 2002), hara dan pH (Bulmer dan Simpson, 2005). Menurut Syukur (2005) lahan pasir pantai memiliki kemampuan menyediakan udara yang berlebihan, sehingga mempercepat pengeringan dan oksidasi bahan organik. Selain itu, intensitas sinar matahari dan suhu yang tinggi, serta angin yang berhembus membawa uap garam yang menyebabkan kesulitan dalam memilih tanaman yang dibudidayakan.

Kesetaraan produktivitas lahan pasir pantai dengan lahan pertanian lainnya perlu ditingkatkan melalui pemanfaatan pupuk hayati dan pupuk bahan organik. Pemanfataan pupuk hayati dikombinasikan dengan pupuk bahan organik diharapkan mampu meningkatkan tingkat produktivitas lahan pasir dalam mengoptimalisasikan dan mempertahankan produksi bawang merah di Indonesia, baik secara kualitas ataupun kuantitas. Salah satu pupuk hayati yang digunakan dalam dunia pertanian saat ini adalah kelompok bakteri rizosfer atau sering dikenal dengan Rizobakteria Pemacu Tumbuh Tanaman (RPTT). Sutariati dan Safuan (2006) mengemukakan bahwa kelompok RPTT tersebut, sekarang lebih dikenal dengan Plant Gowth Promoting Rhizobacteria (PGPR). PGPR berperan dalam meningkatkan pertumbuhan dan produksi tanaman, yang diduga ada hubungannya dengan kemampuan mensintesis hormon tumbuh.

Aplikasi agen hayati merupakan salah satu alternatif yang dikembangkan dalam rangka peningkatan produksi tanaman. Bakteri agen hayati dapat memacu pertumbuhan tanaman dan berperan dalam mekanisme langsung atau tidak langsung melalui pengendalian penyakit untuk mempertahankan produktivitas tanaman. Mekanisme langsung terjadi melalui fiksasi nitrogen, pelarutan fosfat, serta produksi siderofor, fitohormon, dan 1aminocyclopropane-1-carboxylate deaminase, sedangkan mekanisme tidak langsung melalui produksi antibiotik, hidrogen sianida $(\mathrm{HCN})$, dan siderofor; kompetisi relung ekologis (lingkungan tumbuh/ecological niche), dan induksi ketahanan sistemik (Choudhary dan Johri, 2009; Martinez-
Viveros et al., 2010; Glick, 2012; Ahemat dan Kibret, 2014). Namun, penelitian tentang pengaruh isolat PGPR belum banyak dilakukan pada lahan marginal seperti lahan pasir pantai. Penelitian ini bertujuan untuk mendapatkan isolat PGPR yang efektif terhadap pertumbuhan tiga kultivar bawang merah di lahan pasir pantai.

\section{BAHAN DAN METODE}

Penelitian dilaksanakan di lahan pasir pantai Samas, Bantul, Yogyakarta, dilanjutkan di Laboratorium Penyakit Tumbuhan, Laboratorium Ilmu Tanaman, Fakultas Pertanian, dan Laboratorium LPPT Unit 1, Universitas Gadjah Mada, Yogyakarta. Penelitian dilakukan sejak bulan Juni sampai dengan Agustus 2016.

Penelitian menggunakan rancangan kelompok lengkap teracak (RKLT) 2 faktor dengan 3 ulangan. Faktor pertama yaitu kultivar bawang merah, sedangkan faktor kedua yaitu aplikasi suspensi PGPR. Data hasil pengamatan dianalisis secara statistik dengan menggunakan analysis of variance (anova) pada taraf $\alpha=5 \%$ dan dilanjutkan dengan uji jarak berganda Duncan (DMRT) pada taraf uji 5\%.

\section{Isolat PGPR}

Isolat-isolat PGPR yang digunakan diperoleh dari percobaan Istiqomah (2015). Rizobakteria diisolasi dari rizosfer tanaman bawang sehat yang tumbuh di antara tanaman yang menunjukkan gejala terserang penyakit moler. Percobaan ini mengevaluasi kelompok bakteri antagonis, yakni berasal dari kelompok Bacillus (isolat BP25.2: Bacillus methylotrophicus, isolat BP25.6: Bacillus amyloliquefaciens, isolat: BP25.7: Bacillus subtilis) dan kelompok Burkholderia (isolat BrSM 4: Burkholderia cepacia, isolat BrSG 5: Burkholderia seminalis).

\section{Persiapan Lahan dan Pemupukan Lahan}

Sebelum dilakukan penanaman, pasir diairi terlebih dahulu hingga kelembaban yang cukup bagi pertumbuhan awal benih. Kemudian dilakukan pemupukan dengan menggunakan pupuk kandang sebanyak 20 ton ha-1. Selanjutnya saat tanaman berumur 5 HST, dilakukan pemupukan dengan menggunakan pupuk anorganik ZA 200 kg. Pemupukan lanjutan dilakukan saat tanaman berumur 15 hari setelah tanam. Pupuk yang digunakan adalah Urea $90 \mathrm{~kg} \mathrm{ha}^{-1}$ dan SP36 $170 \mathrm{~kg} \mathrm{ha}^{-1}$. Umbi yang telah diberi perlakuan PGPR ditanam dengan jarak tanam $20 \mathrm{~cm} \times 15$ $\mathrm{cm}$. Posisi umbi bagian akar masuk kedalam tanah hingga 2/3 bagian. Untuk tiap lubang tanam dimasukkan 1-2 umbi. Tahapan selanjutnya adalah penyiraman rutin yang dilakukan dua kali sehari, pada pagi dan siang hari.

\section{Perlakuan Benih dengan PGPR}

Isolat PGPR ditumbuhkan dalam media padat Yeast Peptone Agar (YPA) dan diinkubasi selama 48 jam. Koloni bakteri yang tumbuh, kemudian disuspensikan dalam 
medium cair Yeast Peptone Broth (YPB) hingga mencapai kerapatan populasi dengan nilai absorban 106-108 OD menggunakan spektrofotometer.

Umbi bawang merah terlebih dahulu disortir berdasarkan kriteria umbi yaag sehat dan ukuran. Umbi yang dipilih adalah umbi yang terlihat sehat atau tanpa cacat luka maupun busuk. Setelah itu, umbi ditimbang sesuai kebutuhan, yakni sebanyak $3.2 \mathrm{~kg}$ kultivar Crok, $2.7 \mathrm{~kg}$ kultivar Tiron, dan $4.3 \mathrm{~kg}$ kultivar Tuk-tuk. Umbi bawang merah selanjutnya direndam dalam $120 \mathrm{~mL}$ suspensi PGPR yang ditambahkan air hingga mencapai $3 \mathrm{~L}$ selama \pm 8 jam, untuk masing-masing perlakuan. Umbi bawang merah yang telah direndam kemudian dikeringanginkan di tempat yang teduh sebelum proses penanaman.

\section{Pengaruh Perlakuan terhadap Kandungan Hormon IAA}

Analisis ini dilakukan pada daun tanaman bawang merah. Analisis dilakukan sebagai pembuktian peran PGPR dalam menginduksi kandungan hormon IAA dalam tubuh tanaman dengan metode HPLC $20 \mu \mathrm{L}$ (Sukmadi, 2012).

\section{Pengaruh Perlakuan terhadap Pertumbuhan Tanaman Bawang Merah}

Pengamatan pertumbuhan dilakukan dengan mengukur tinggi tanaman, menghitung jumlah daun yang terbentuk dan mengukur luas akar tanaman yang segar dengan menggunakan Leaf Area Meter. Variabel pengamatan tinggi tanaman dan jumlah daun tanaman diukur pada saat tanaman berumur 1, 3, dan 5 MST. Pengamatan jumlah akar dan luas akar diamati pada saat tanaman berumur 5 MST untuk setiap tanaman sampel, yang berjumlah 9 tanaman per bedeng.

Pengaruh Perlakuan terhadap Kadar Lengas Pasir Pantai dan Residu $N$ dan $P$

Pengamatan dilakukan dengan mengambil pasir pada area rizosfer tanaman dengan kedalaman 25-30 cm untuk setiap unit perlakuan. Pasir tersebut kemudian disterilkan selama 24 jam dan dilanjutkan proses analisis dengan metode gravimetri. Analisis kadar lengas dilakukan pada akhir fase vegetatif tanaman dan telah memasuki fase generatif tanaman. Selanjutnya, residu $\mathrm{N}$ dan $\mathrm{P}$ diamati pada saat tanaman telah melewati fase generatif atau setelah selesai masa panen. Perhitungan residu dilakukan dengan metode destilasi Kjeldahl dan Olsen (ACIAR, 1990; Olsen et al.1954).

\section{Pengaruh Perlakuan terhadap Hasil Tanaman Bawang Merah}

Pengamatan terhadap hasil dilakukan pada minggu ke 9 setelah tanam, dengan menimbang umbi yang dipanen pada petak produksi. Selanjutnya umbi dikeringanginkan selama seminggu, kemudian bobot dikonversi ke produksi per hektar. Adapun rumus perhitungan yang digunakan adalah:
Umbi petak produksi $\left(\right.$ ton $\left.\mathrm{ha}^{-1}\right)=\frac{\left\{\frac{\text { Luas lahan total }}{\text { Luas petak produksi }} \times \text { Bobot segar }(g)\right\}}{1.000 .000}$

\section{Pengaruh Perlakuan terhadap Persentase Insidensi} Penyakit Moler dan Biomassa Gulma

Pengamatan insidensi penyakit moler dilakukan dengan menghitung jumlah tanaman yang menunjukkan gejala penyakit moler pada saat tanaman berumur 5 dan 8 MST, dengan menggunakan rumus:

Presentase kejadian penyakit moler $=$ $\frac{\text { Jumlah tanaman terserang atau dicabut }}{\text { Jumlah total tanaman dalam petak produksi }} \times 100 \%$

Biomassa gulma diamati dengan mencabut gulma secara keseluruhan untuk masing-masing petak pengamatan. Gulma yang dicabut kemudian dioven selama \pm 3 hari dengan suhu oven $60{ }^{\circ} \mathrm{C}$ yang bertujuan untuk mendapatkan bobot konstan gulma.

\section{HASIL DAN PEMBAHASAN}

Pengaruh Perlakuan terhadap Kandungan Hormon IAA

Hasil penelitian menunjukkan pengaruh yang tidak berbeda nyata yang mengindikasikan bahwa setiap isolat PGPR mampu menghasilkan hormon IAA pada setiap

Tabel 1. Kandungan hormon IAA tanaman bawang merah Kultivar Crok, Tiron, dan Tuk-tuk pada 5 MST

\begin{tabular}{lcc}
\hline Kultivar & Perlakuan PGPR & $\begin{array}{c}\text { Kandungan } \\
\text { IAA }\left(\mathrm{mg} \mathrm{kg}^{-1}\right)\end{array}$ \\
\hline Crok & Kontrol & 19.13 \\
& BP25.2 & 22.13 \\
& BP25.6 & 3.89 \\
& BP25.7 & 16.78 \\
Tiron & BrSM 4 & 16.32 \\
& BrSG 5 & 22.46 \\
& Kontrol & 39.64 \\
& BP25.2 & 20.62 \\
& BP25.6 & 14.97 \\
Tuk-tuk & BP25.7 & 12.07 \\
& BrSM 4 & 24.99 \\
& BrSG 5 & 28.61 \\
& Kontrol & 8.27 \\
& BP25.2 & 31.27 \\
& BP25.6 & 12.54 \\
& BP25.7 & 15.40 \\
& BrSM 4 & 18.85 \\
& BrSG 5 & 41.41 \\
\hline
\end{tabular}




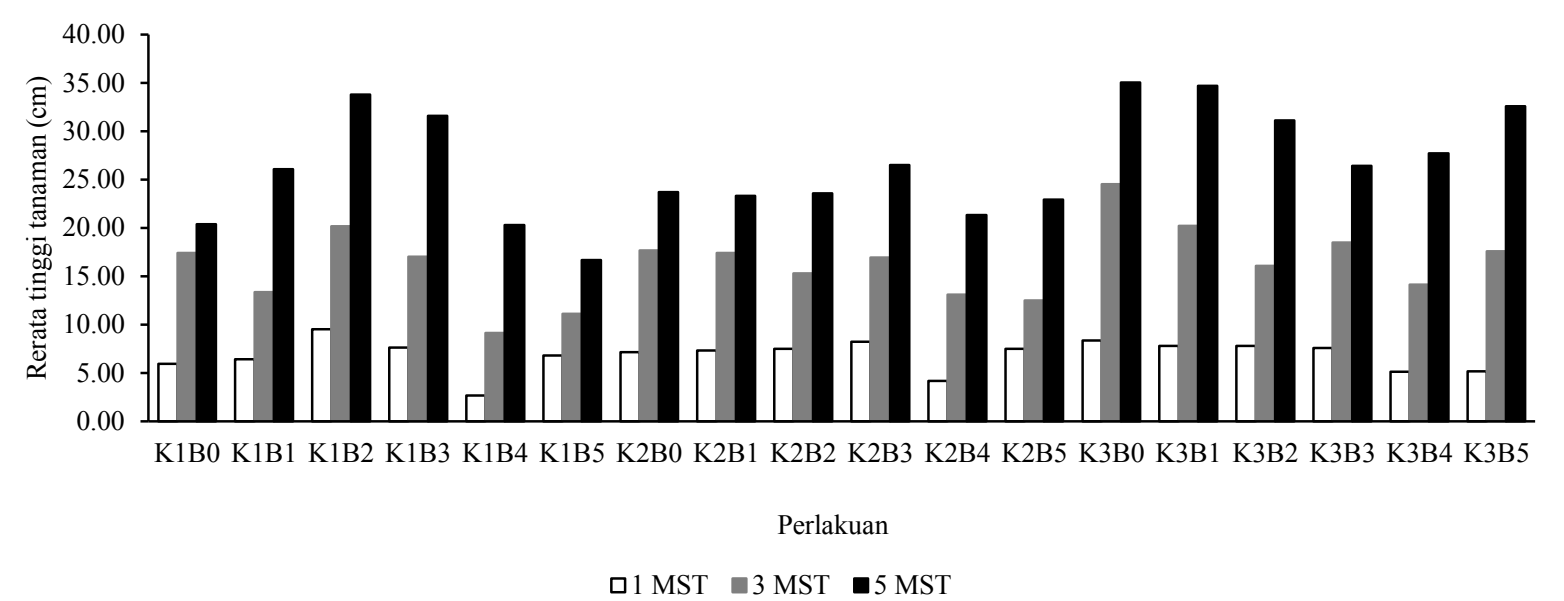

Gambar 1. Pengaruh perlakuan terhadap tinggi tanaman bawang merah pada 1, 3, dan 5 MST. K1 = Crok; K2 = Tiron; K3 = tuk-tuk; B0 = Tanpa PGPR; B1= BP25.2 (Bacillus methylotrophicus); B2 = BP25.6 (Bacillus amyloliquefaciens); B3 = BP25.7 (Bacillus subtilis); B4 = BrSM 4 (Burkholderia cepacia); B5 = BrSG 5 (Burkholderia seminalis)

kultivar (Tabel 1). Hal yang sama juga dilaporkan oleh Kafrawi et al. (2015) bahwa PGPR mampu menginduksi IAA melalui satu atau lebih mekanisme dalam meningkatkan pertumbuhan tanaman, misalnya pengendali biologi melalui kompetisi, produksi antibiotik atau siderofor, induksi resistensi tanaman, produksi fitohormon, dan peningkatan ketersediaan hara $\mathrm{N}$ dan $\mathrm{P}$, serta peningkatan kelarutan fosfat organik dan anorganik.

\section{Pengaruh Perlakuan terhadap Pertumbuhan Tanaman}

Adanya aktivitas IAA dalam daun tanaman diduga berpengaruh terhadap pertumbuhan tanaman bawang merah. Hasil penelitian menunjukkan bahwa perlakuan pemberian PGPR memberikan pengaruh yang tidak berbeda nyata terhadap pertumbuhan tinggi tanaman yang diamati (Gambar 1). Hal yang sama juga ditunjukkan pada variabel jumlah daun, begitu juga jenis kultivar yang digunakan (Gambar 2). Perbedaan yang tidak nyata pada variabel tinggi dan jumlah daun diduga disebabkan karena masing-masing isolat PGPR yang digunakan mampu menginduksi hormon IAA. Hasil pengamatan lainnya menunjukkan bahwa kultivar berpengaruh terhadap jumlah akar dan luas akar tanaman bawang merah pada lahan berpasir. Kultivar Tiron menunjukkan nilai 106.1 helai akar dengan luas akar sebesar $13.85 \mathrm{~cm}^{2} \mathrm{~g}^{-1}$ yang nyata lebih tinggi daripada kultivar Crok yang menunjukkan nilai jumlah akar sebesar 82.5 helai, dan berbeda nyata pada parameter luas akar kultivar Tuk-tuk dengan nilai sebesar $9.45 \mathrm{~cm}^{2} \mathrm{~g}^{-1}$ (Tabel 2). Kultivar Tiron diketahui memiliki sifat adaptif terhadap lingkungan dan daya tumbuh yang baik dalam kondisi dibudidayakan pada lahan pertanian pada umumnya bahkan sampai pada lahan pasir (Tuhuteru et al., 2016).

\section{Kondisi Kadar Lengas Tanah dan Residu $N$ dan $P$}

Hasil penelitian menunjukkan adanya pengaruh interaksi antara perlakuan PGPR dengan kultivar bawang merah yang diuji terhadap variabel persentase kadar lengas pasir (Tabel 3). Kadar lengas tertinggi sesuai hasil analisis ditunjukkan oleh PGPR isolat BrSM 4 yang dikombinasikan kultivar Tuk-tuk sebesar $2.49 \%$ yang berbeda nyata dengan perlakuan PGPR isolat BP25.7 dengan kultivar Crok sebesar $0.24 \%$. Hal ini menunjukkan bahwa benar isolat BrSM 4

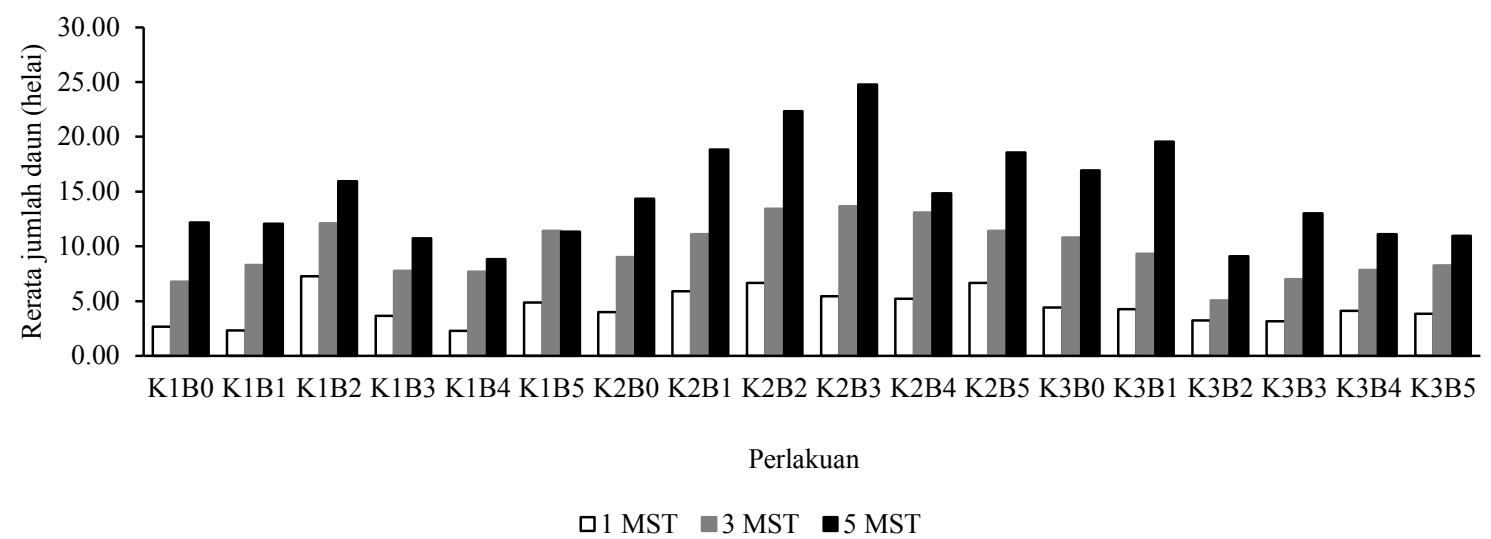

Gambar 2. Pengaruh perlakuan terhadap jumlah daun tanaman bawang merah pada 1, 3, dan 5 MST. K1 = Crok; K2= Tiron; K3 = tuk-tuk; B0 = Tanpa PGPR; B1 = BP25.2 (Bacillus methylotrophicus); B2 = BP25.6 (Bacillus amyloliquefaciens); B3 = BP25.7 (Bacillus subtilis); B4 = BrSM 4 (Burkholderia cepacia); B5 = BrSG 5 (Burkholderia seminalis) 
Tuhuteru et al. / J. Agron. Indonesia 47(1):53-60

Tabel 2. Jumlah akar (helai) dan luas akar $\left(\mathrm{cm}^{2} \mathrm{~g}^{-1}\right)$ tanaman bawang merah varietas Crok, Tiron, dan Tuk-tuk pada 5 MST

\begin{tabular}{|c|c|c|c|c|c|c|c|c|}
\hline \multirow{2}{*}{ Variabel } & \multirow{2}{*}{ Kultivar } & \multicolumn{6}{|c|}{ Perlakuan PGPR } & \multirow{2}{*}{ Rerata } \\
\hline & & Kontrol & BP25.2 & BP25.6 & BP25.7 & BrSM 4 & BrSG 5 & \\
\hline \multirow{4}{*}{$\begin{array}{l}\text { Jumlah } \\
\text { akar } \\
\text { (helai) }\end{array}$} & Crok & 97.7 & 72.2 & 66.0 & 91.2 & 95.1 & 72.7 & $82.5 b$ \\
\hline & Tiron & 105.8 & 78.7 & 132.2 & 89.1 & 122.2 & 108.5 & $106.1 \mathrm{a}$ \\
\hline & Tuk-tuk & 77.8 & 110.2 & 86.9 & 94.7 & 88.7 & 80.0 & $89.7 \mathrm{ab}$ \\
\hline & Rerata & 93.7 & 87.0 & 95.0 & 91.7 & 102.0 & 87.0 & $(-)$ \\
\hline \multicolumn{9}{|c|}{ CV: 26.99} \\
\hline \multirow{4}{*}{$\begin{array}{l}\text { Luas akar } \\
\left(\mathrm{cm}^{2} \mathrm{~g}^{-1}\right)\end{array}$} & Crok & 9.48 & 9.99 & 8.47 & 10.34 & 11.74 & 9.39 & $9.90 \mathrm{~b}$ \\
\hline & Tiron & 14.23 & 15.61 & 12.39 & 14.54 & 15.59 & 10.73 & $13.85 \mathrm{a}$ \\
\hline & Tuk-tuk & 7.31 & 11.19 & 8.35 & 9.10 & 9.84 & 10.91 & $9.45 b$ \\
\hline & Rerata & 10.34 & 12.26 & 9.74 & 11.33 & 12.39 & 10.34 & $(-)$ \\
\hline
\end{tabular}

Keterangan: Angka rerata dalam satu kolom dan/atau baris yang diikuti oleh huruf sama tidak berbeda nyata menurut DMRT dengan $\alpha=$ $5 \%$. (-) = tidak ada interaksi antar faktor yang diuji; data ditransformasi dengan log x (3 MST); CV = coefficient of variation

Tabel 3. Kadar lengas tanaman bawang merah kultivar Crok, Tiron, dan Tuk-tuk pada 5 MST

\begin{tabular}{|c|c|c|c|c|c|c|c|}
\hline \multirow{2}{*}{ Kultivar } & \multicolumn{6}{|c|}{ Kadar lengas (\%) } & \multirow{2}{*}{ Rerata } \\
\hline & Kontrol & BP25.2 & BP25.6 & BP25.7 & BrSM 4 & BrSG 5 & \\
\hline Crok & $1.08 \mathrm{efg}$ & $0.45 \mathrm{jk}$ & $0.584 \mathrm{ij}$ & $0.24 \mathrm{k}$ & $0.76 \mathrm{ghij}$ & 0.93 fghi & 0.67 \\
\hline Tiron & $0.98 \mathrm{fgh}$ & 0.69hij & $0.652 \mathrm{hij}$ & $1.34 \mathrm{cde}$ & $1.19 \mathrm{def}$ & 0.79ghij & 0.94 \\
\hline Tuk-tuk & $1.54 \mathrm{c}$ & $1.50 \mathrm{~cd}$ & $1.862 b$ & $1.89 \mathrm{~b}$ & $2.49 \mathrm{a}$ & $2.40 \mathrm{a}$ & 1.95 \\
\hline Rerata & 1.20 & 0.88 & 1.033 & 1.16 & 1.48 & 1.37 & $(+)$ \\
\hline
\end{tabular}

Keterangan: Angka rerata dalam satu kolom dan/atau baris yang diikuti oleh huruf sama tidak berbeda nyata menurut DMRT dengan $\alpha=$ $5 \%$. (-) = tidak ada interaksi antar faktor yang diuji; data ditransformasi dengan log x (3 MST); CV = coefficient of variation

merupakan isolat yang respon tanggapannya lebih baik dibandingkan dengan isolat lainnya dan Tuk-tuk merupakan kultivar yang memiliki kemampuan tumbuh di lahan pasir layaknya kultivar Tiron. Presentase kandungan lengas pasir ini didukung oleh hasil penelitian Yudono et al. (2002), yang menunjukkan bahwa kadar lengas tersedia pasir berkisar dari $1.55-3.05 \%$ dengan pori makro $20.32 \%$ dan pori mikro $2.04 \%$.

Hasil penelitian menunjukkan adanya interaksi antara perlakuan PGPR dengan kultivar bawang merah terhadap residu $\mathrm{N}$ dan $\mathrm{P}$ di lingkungan rizosfer (Tabel 4). Residu $\mathrm{N}$ terendah ditunjukkan oleh kultivar Tuk-Tuk yang diberi perlakuan isolat BP25.2 (Bacillus methylotrophicus) sebesar $0.05 \%$ atau residu tersisa sebesar 5\%, yang diikuti oleh kultivar Crok yang diberi isolat BP25.7 (Bacillus subtilis) dengan nilai residu sebesar $0.08 \%$ atau setara $8 \%$, dan kemudian diikuti kultivar Tiron dengan isolat BrSG 5 (Burkholderia seminalis) dengan nilai residu sebesar $0.11 \%$ atau setara 11\% (Tabel 4). Sedangkan, residu P terendah ditunjukkan oleh kultivar Crok yang diberi isolat BP25.7 (Bacillus subtilis) sebesar 0.22 ppm P yang tersisa, diikuti oleh isolat BP25.2 (Bacillus methylotrophicus) sebesar 0.24 ppm dengan kultivar yang sama, kemudian diikuti oleh kultivar Tuk-tuk yang diberi isolat BrSG 5 (Burkholderia seminalis), dengan nilai residu yang sama yakni, sebesar $0.24 \mathrm{ppm}$. Hal ini menunjukkan bahwa di area rizosfer tanaman ditemukan adanya residu $\mathrm{N}$ dan $\mathrm{P}$.

Adapun mekanismenya adalah PGPR mereduksi N mengubahnya menjadi nitrat yang diserap oleh tanaman. PGPR membawa $\mathrm{N}$ dan melepaskannya dalam sitoplasma sel tanaman dan merangsang sel untuk membelah. Residu terendah yang ditemukan dari hasil analisis $\mathrm{N}$ dan $\mathrm{P}$ pada area rizosfer menunjukkan bahwa $\mathrm{N}$ dan $\mathrm{P}$ yang diserap tanaman dalam jumlah banyak, sehingga yang tersisa sangat rendah. Diketahui bahwa N dibutuhkan oleh tanaman dalam meningkatkan pertumbuhan vegetatif tanaman karena $\mathrm{N}$ diketahui berfungsi untuk membentuk protoplasma, memperbanyak dan memperpanjang sel tanaman termasuk bagian batang tanaman, sehingga meningkatkan tinggi tanaman (Widiyawati et al. 2014). Hal ini mengindikasikan bahwa isolat BP25.2 (Bacillus methylotrophicus), BP25.7 (Bacillus subtilis) dan BrSG 5 (Burkholderia seminalis) efektifdalam menyediakan unsur $\mathrm{N}$ pada pertanaman bawang merah di lahan pasir. Hal yang sama juga ditunjukkan pada residu $\mathrm{P}$, yang menunjukkan isolat BP25.7, BP25.2 dan BrSG 5 efektif dalam menyediakan $\mathrm{P}$ pada pertanaman bawang merah. Kemampuan menyisakan residu $\mathrm{N}$ dan $\mathrm{P}$ tidak terlepas dari kandungan lengas pasir pantai, yaitu 
Tabel 4. Residu N dan P di lingkungan rizosfer tanaman bawang merah kultivar Crok, Tiron, dan Tuk-tuk pada 3 MST

\begin{tabular}{|c|c|c|c|c|c|c|c|c|}
\hline \multirow{2}{*}{ Residu } & \multirow{2}{*}{ Varietas } & \multicolumn{6}{|c|}{ Perlakuan PGPR } & \multirow{2}{*}{ Rerata } \\
\hline & & Kontrol & BP25.2 & BP25.6 & BP25.7 & BrSM 4 & BrSG 5 & \\
\hline \multirow[t]{4}{*}{$\mathrm{N}(\%)$} & Crok & $0.14 \mathrm{abc}$ & $0.06 \mathrm{fg}$ & $0.12 \mathrm{ed}$ & $0.08 \mathrm{f}$ & $0.13 \mathrm{cde}$ & $0.11 \mathrm{ed}$ & 0.11 \\
\hline & Tiron & $0.14 \mathrm{bcd}$ & $0.14 \mathrm{bcd}$ & $0.13 \mathrm{cde}$ & $0.16 \mathrm{ab}$ & $0.17 \mathrm{a}$ & $0.11 \mathrm{e}$ & 0.14 \\
\hline & Tuk-tuk & $0.14 \mathrm{bcd}$ & $0.05 \mathrm{~g}$ & $0.15 \mathrm{abc}$ & $0.14 \mathrm{bcd}$ & $0.15 \mathrm{abc}$ & $0.14 \mathrm{bcd}$ & 0.13 \\
\hline & Rerata & 0.14 & 0.08 & 0.13 & 0.12 & 0.15 & 0.12 & $(-)$ \\
\hline \multicolumn{9}{|c|}{ CV: 10.55} \\
\hline \multirow[t]{4}{*}{$\mathrm{P}(\mathrm{ppm})$} & Crok & $0.35 \mathrm{~d}$ & $0.24 \mathrm{~g}$ & $0.28 \mathrm{f}$ & $0.22 \mathrm{~g}$ & $0.36 \mathrm{~d}$ & $0.36 \mathrm{~d}$ & 0.30 \\
\hline & Tiron & $0.32 \mathrm{e}$ & $0.30 \mathrm{ef}$ & $0.30 \mathrm{ef}$ & $0.40 \mathrm{c}$ & $0.28 \mathrm{f}$ & $0.24 \mathrm{~g}$ & 0.30 \\
\hline & Tuk-tuk & $0.48 \mathrm{a}$ & $0.43 b$ & $0.43 b$ & $0.39 \mathrm{c}$ & $0.40 \mathrm{bc}$ & $0.35 \mathrm{~d}$ & 0.41 \\
\hline & Rerata & 0.38 & 0.32 & 0.33 & 0.34 & 0.35 & 0.31 & $(-)$ \\
\hline
\end{tabular}

Keterangan: Angka rerata dalam satu kolom dan/atau baris yang diikuti oleh huruf sama tidak berbeda nyata menurut DMRT dengan $\alpha=$ $5 \%$. (-) = tidak ada interaksi antar faktor yang diuji; data ditransformasi dengan $\log$ x (3 MST); CV = coefficient of variation

persentase kandungan lengas pasir berkisar dari 1.55-3.05\% dengan pori makro $20.32 \%$ dan pori mikro $2.04 \%$ (Yudono et al., 2002)

\section{Pengaruh Perlakuan terhadap Hasil Tanaman Bawang Merah}

Hasil penelitian menunjukkan adanya pengaruh interaksi kultivar dengan perlakuan PGPR terhadap variabel bobot umbi produksi yang dikeringanginkan (Tabel 5). Seperti yang telah dilaporkan oleh Jumini et al. (2011) bahwa pada setiap kultivar tanaman selalu terdapat perbedaan respon genotipe pada berbagai kondisi lingkungan tempat tumbuhnya. Keadaan inilah yang menyebabkan perbedaan pertumbuhan dari masing-masing kultivar bawang merah. Dapat dikatakan bahwa adanya peningkatan proses metabolisme pada kultivar Tiron menyebabkan peningkatan pembentukan karbohidrat, protein, dan lemak yang pada akhirnya potensi hasil panen dapat lebih meningkat. Berdasarkan keseluruhan kombinasi perlakuan, hasil terbaik ditunjukkan oleh kultivar Tiron yang dikombinasikan dengan perlakuan isolat BrSM 4 (Burkholderia cepacia), dengan nilai sebesar 3.75 ton $\mathrm{ha}^{-1}$ yang berbeda nyata dengan kultivar Crok yang dikombinasikan dengan isolat BP25.7 (Bacillus subtilis) (0.70 ton ha $\left.{ }^{-1}\right)$.

Peningkatan bobot kering diketahui dapat terjadi bila fotosintesis lebih besar dari respirasi. Hal ini dibuktikan dengan adanya aktivitas bakteri dalam tubuh tanaman dalam perannya sebagai fitohormon terutama IAA yang diduga dapat meningkatkan permeabilitas dinding sel yang akan meningkatkan penyerapan unsur hara pembentuk klorofil yang sangat diperlukan untuk meningkatkan fotosintesis dan berpengaruh pada hasil produksi tanaman. Selain itu, diduga akibat dari kandungan unsur hara dari pupuk kandang yang diberikan dan bersamaan dengan adanya bantuan bakteri di dalam jaringan tanaman, mampu diserap tanaman untuk proses metabolisme seperti pembentukan karbohidrat yang sebagian besar ditranslokasikan untuk pembentukan umbi dan pada fase ini kalium berperan dalam pembentukan dan pembesaran umbi (Tuhuteru et al., 2016).

Pengaruh Perlakuan terhadap Persentase Kejadian Penyakit Moler dan Biomassa Gulma

Hasil penelitian menunjukkan bahwa perlakuan PGPR tidak berpengaruh nyata pada variabel persentase insidensi

Tabel 5. Bobot umbi produksi yang dikeringanginkan (ton ha ${ }^{-1}$ ) kultivar Crok, Tiron, dan Tuk-tuk pada 9 MST

\begin{tabular}{|c|c|c|c|c|c|c|c|}
\hline \multirow{2}{*}{ Kultivar } & \multicolumn{6}{|c|}{ Bobot umbi (ton ha' ${ }^{-1}$ ) } & \multirow{2}{*}{ Rerata } \\
\hline & Kontrol & BP25.2 & $\mathrm{BP} 25.6$ & BP25.7 & BrSM 4 & BrSG 5 & \\
\hline Crok & $2.12 \mathrm{bcde}$ & $1.13 \mathrm{cdef}$ & $1.73 \mathrm{ef}$ & $0.70 \mathrm{f}$ & $1.45 \mathrm{cdef}$ & $1.35 \mathrm{def}$ & 1.41 \\
\hline Tiron & $2.75 \mathrm{abc}$ & $2.56 \mathrm{abcd}$ & $2.72 \mathrm{abc}$ & $3.53 \mathrm{ab}$ & $3.75 \mathrm{a}$ & $3.74 \mathrm{a}$ & 3.17 \\
\hline Tuk-tuk & $1.50 \mathrm{cdef}$ & $1.93 \mathrm{cde}$ & $1.39 \mathrm{def}$ & $1.81 \mathrm{cdef}$ & $1.05 \mathrm{ef}$ & $1.12 \mathrm{ef}$ & 1.47 \\
\hline Rerata & 2.12 & 1.87 & 1.94 & 2.02 & 2.08 & 2.07 & $(+)$ \\
\hline
\end{tabular}

Keterangan: Angka rerata dalam satu kolom dan/atau baris yang diikuti oleh huruf sama tidak berbeda nyata menurut DMRT dengan $\alpha=$ $5 \%$. (-) = tidak ada interaksi antar faktor yang diuji; data ditransformasi dengan log x (3 MST); CV = coefficient of variation 
penyakit moler maupun biomassa gulma yang diamati. Hal ini diduga akibat sifat antagonis yang dimiliki oleh isolat PGPR yang digunakan. Namun, kultivar menunjukkan perbedaan nyata pada insidensi penyakit moler pada tanaman bawang merah di lahan berpasir. Hasil penelitian menunjukkan nilai tertinggi ditunjukkan oleh kultivar Crok sebesar, $61.33 \%$ yang artinya kultivar Crok rentan terhadap serangan moler dibanding kultivar Tiron $(21.33 \%)$ dan Tuktuk (34.67\%) (Tabel 6). Ketahanan yang ditunjukkan ini terkait dengan kemampuan tanaman dalam mempertahankan sistem imun tubuhnya dalam menanggapi adanya indikasi serangan patogen penyakit moler. Sedangkan untuk variabel biomassa gulma, hasil penelitian menunjukkan bahwa kultivar Tuk-tuk sangat disukai oleh keberadaan gulma di lingkungan tumbuhnya. Hal ini ditunjukkan oleh nilai tertinggi biomassa gulma, yakni sebesar $86.70 \mathrm{~g}$, yang artinya kultivar Tuk-tuk rentan ditumbuhi oleh banyak gulma, dibanding dengan kultivar Tiron dan Crok yang menunjukkan nilai sebesar $69.78 \mathrm{~g}$ dan $71.33 \mathrm{~g}$ (Tabel 6). Hal ini diduga bahwa eksudat yang dikeluarkan oleh akar Tuk-tuk disukai oleh gulma yang akhirnya tumbuh bersama-sama dengan tanaman pokok. Hal ini didukung oleh pernyataan Ahemad dan Kibret (2014) bahwa pada lingkungan rizosfer yang dinamis dan kaya akan sumber energi dari senyawa organik yang dikeluarkan oleh akar tanaman berupa eksudat yang mengandung asam amino, gula (glukosa, fruktosa, ribose, galaktosa), asam organik (oxalic, malic, fumaric, malonat, piruvat), purin/nukleosida

Tabel 6. Persentase insidensi penyakit moler (\%) dan biomassa gulma (g) tanaman bawang merah kultivar Crok, Tiron, dan Tuk-tuk

\begin{tabular}{ccc}
\hline Perlakuan & $\begin{array}{c}\text { Variabel pengamatan } \\
\text { Insidensi Penyakit } \\
(\%)\end{array}$ & $\begin{array}{c}\text { Biomassa gulma } \\
(\mathrm{g})\end{array}$ \\
\hline Kultivar & & \\
Crok & $61.33 \mathrm{a}$ & $71.33 \mathrm{~b}$ \\
Tiron & $21.33 \mathrm{~b}$ & $69.78 \mathrm{~b}$ \\
Tuk-tuk & $34.67 \mathrm{ab}$ & $86.70 \mathrm{a}$ \\
\hline PGPR & & \\
Kontrol & 41.33 & 87.37 \\
BP25.2 & 32.00 & 70.95 \\
BP25.6 & 40.00 & 54.45 \\
BP25.7 & 36.00 & 57.34 \\
BrSM 4 & 46.67 & 90.51 \\
BrSG 5 & 38.67 & 95.01 \\
\hline CV & 16.98 & 16.78 \\
\hline
\end{tabular}

Keterangan: Angka rerata dalam satu kolom dan/atau baris yang diikuti oleh huruf sama tidak berbeda nyata menurut DMRT dengan $\alpha=5 \%$. $(-)=$ tidak ada interaksi antar faktor yang diuji, data ditransformasi dengan $\log \mathrm{x}$ (3 MST), CV = coefficient of variation (adenine, guanine, cytidine, uridine), dan ion-ion organik $\left(\mathrm{HCO}_{3}^{-}, \mathrm{OH}^{-}, \mathrm{H}^{+}, \mathrm{CO}_{2} \mathrm{H}_{3}\right)$. Hal inilah yang memungkinkan disukai oleh gulma di area pertanaman kultivar Tuk-tuk.

\section{KESIMPULAN}

Hasil penelitian menunjukkan bahwa semua isolat PGPR yang diuji memiliki kemampuan memproduksi IAA, dengan konsentrasi tertinggi ditunjukkan oleh isolat BrSG.5 (Burkholderia seminalis) yang dikombinasikan dengan ketiga jenis kultivar $\left(22.46 \mathrm{mg} \mathrm{kg}^{-1}, 28.61 \mathrm{mg} \mathrm{kg}^{-1}, 41.41\right.$ $\mathrm{mg} \mathrm{kg}^{-1}$ ). Isolat BP25.2 (Bacillus methylotrophicus) efektif menghasilkan N (0.05\%). Isolat BP25.7 (Bacillus subtilis) efektif menghasilkan residu $\mathrm{P}(0.22 \mathrm{ppm})$.

\section{UCAPAN TERIMA KASIH}

Ucapan terima kasih saya sampaikan kepada Lembaga Pengelola Dana Pendidikan Republik Indonesia (LPDP RI) yang telah mendukung penelitian ini secara material.

\section{DAFTAR PUSTAKA}

[ACIAR] Australian Centre for International Agricultural Research. 1990. Laboratory techniques for plant and soil analysis. p. 149. In Lisle, L., J. Gaudron, R. Lefroy $(E d s$.). UNE-ACIAR-Crawford Fund. Department of Agronomy and Soil Science, University of New England, Armidale, Australia and Australian Centre for International Agricultural Research.

Ahemad, M., M. Kibret, 2014. Mechanisms and applications of plant growth promoting rhizobacteria. Curr. Perspective J. King Saud Univ. Sci. 26:1-20.

Al-Omran, A.M., A.M. Falatah, A.S. Sheta, A.R.Al-Harbi. 2004. Clay deposits for water management of sandy soils. Arid Land Res. Manag. 1:171-183.

Badan Riset Kelautan dan Perikanan. 2007. Departemen Kelautan dan Perikanan Republik Indonesia. https:// www.brkp.go.id. [21 Februari 2019].

Bulmer, E.C., D.G. Simpson. 2005. Soil compaction and water content as factors affecting the growth of lodgapole pine seedling on sandy clay loam soil. Can. J. Soil Sci. 85:667-679.

Choudhary, D.K., B.N. Johri. 2009. Interactions of Bacillus spp. and plants with special reference to induced systemic resistance (ISR). Microbiol. Res. 164:49351.

Glick, B. 2012. Plant growth-promoting bacteria: mechanisms and applications. Scientifica 20:1-15. 
Istiqomah, D. 2015. Seleksi rizobakteri bawang merah untuk mengendalikan penyakit moler. Tesis. Progam Studi Fitopatologi, Fakultas Pertanian. Universitas Gadjah Mada. Yogyakarta.

Jumini, A. Marliah, R. Fahmi. 2011. Respon beberapa varietas bawang merah akibat perbedaan jarak tanam dalam sistem tumpangsari pada lahan bekas tsunami. J. Floratek 6:55-61.

Kafrawi, Z. Kumalawati, S. Mulyani, 2015. Skrining isolat plant gowth promoting rhizobacteri (PGPR) dari pertanaman bawang merah (Allium ascalonicum) di Gorontalo. hal. 133-139. dalam Tim Editor. Seminar Nasional Mikrobiologi Kesehatan dan Lingkungan. Makassar 29 Januari 2015.

Kertonegoro, B.D. 2001. Gumuk pasir pantai di D.I. Yogyakarta: Potensi dan pemanfaatannya untuk pertanian berkelanjutan. hal. 46-54. dalam Tim Editor (Eds). Pemanfaatan Sumberdaya Lokal Untuk Pembangunan Pertanian Berkelanjutan. Yogyakarta 2 Oktober 2001.

Martínez-Viveros, O., M.A. Jorquera, D.E. Crowley, G. Gajardo, M.L. Mora. 2010. Mechanisms and practical considerations involved in plant growth promotion by rhizobacteria. J. Soil Sci. Plant Nutr. 10:293-319.

Oliver, Y.M., K.R.J. Smethem. 2002. Predicting water balance in a sandy soil: Model sensitivity to the variability of measured and near saturatet hidraulic properties. Australian Soil Res. 43:87-96.

Olsen, S.R., C.V. Cole, F. S. Watanabe, L.A. Dean. 1954. Estimation of available $\mathrm{P}$ in soils by extraction with sodium bicarbonate. USD Acir. USA.

Parwata, A.M.G.I., D. Indradewa, P. Yudono, D.B. Kertonegoro, R. Kusmarwiyah. 2014. Respon pertumbuhan dan hasil tanaman jarak pagar (Jatropha curcas L.) terhadap cekaman kekeringan di lahan pasir pantai pada tahun pertama siklus produksi. J. Agron. Indonesia 42:59-65.

Sari, V., Miftahudin, Sobir. 2017. Keragaman genetik bawang merah (Allium cepa L.) berdasarkan marka morfologi dan ISSR. J. Agron. Indonesia 45:175181 .

Sutariati, G.A.K., L.O. Safuan. 2006. Perlakuan benih dengan rizobakteri meningkatkan mutu benih dan hasil cabai (Capsicum annuum L). J. Agron. Indonesia 40:125-131.

Sukmadi, 2012. Aktivitas fitohormon indole-3-acetic acid (IAA) dari beberapa isolat bakteri rizosfer dan endofit. J. Sains Tek. 14:221-227.

Syukur, A. 2005. Pengaruh pemberian bahan organik terhadap sifat-sifat tanah dan pertumbuhan caisin di tanah pasir pantai. J. Ilmu Tanah Ling. 5:30-38.

Tuhuteru, S., E. Sulistyaningsih, A. Wibowo. 2016. Effects of plant growth promoting rhizobacteria (PGPR) on growth and yield of shallot in sandy coastal land. Ilmu Pertanian (Agric.Sci.) 1:105-110.

Widiyawati, I., Sugiyanta, A. Junaedi, R. Widyastuti. 2014. Peran bakteri penambat nitrogen untuk mengurangi dosis pupuk nitrogen anorganik pada padi sawah. J. Agron. Indonesia 42:96-102.

Walter, A., W.K. Silk, U. Schur. 2000. Effect of soil pH on growth and cation deposition in the root tip of Zea mays L. Plant Growth Regul. 19:65-76.

Yudono, P., D. Kastono, S. Purwanti, Sukirno, B.Dj. Kertonegoro, S. Hardyastuti, R. Witjaksono, dan Soenoeadji. 2002. Aplikasi Unit Percontohan Agribisnis Terpadu di Lahan Pantai Propinsi Daerah Istimewa Yogyakarta. Kerjasama Fakultas Pertanian UGM dan Dinas Pertanian Propinsi DIY, ID. 